\title{
KS. LUDWIK RUCZKA (1814-1896), PROBOSZCZ KOLBUSZOWSKI, DZIEKAN MIELECKI, POSEŁ SEJMU KRAJOWEGO WE LWOWIE I WIEDEŃSKIEJ RADY PAŃSTWA, ,OJCIEC" SYBIRAKÓW W 115. ROCZNICE SMIERCI
}

30 XI 1896 r. zakończył życie w Kolbuszowej ks. Ludwik Ruczka, od roku 1848 aż do swojej śmierci proboszcz miejscowej parafii, a ponadto poseł Sejmu Krajowego we Lwowie oraz wiedeńskiej Rady Państwa. Był człowiekiem, który zasłużył się wielce dla parafii kolbuszowskiej oraz samego miasta, a szczególnie w ratowaniu galicyjskich powstańców styczniowych.

Ks. Ludwik Ruczka urodził się 16 IX 1814 r. w Szlachtowej jako syn Franciszka i Domicelli z domu Wisłockiej. W roku 1836 rozpoczął naukę w Seminarium Duchownym w Tarnowie. Święcenia kapłańskie przyjął w 1839 r.; wikary w Oleśnie koło Dąbrowy Tarnowskiej oraz w Wadowicach. Wykładowca w Instytucie Teologicznym w Tarnowie. Po rezygnacji z pracy pedagogicznej, na początku 1848 r. instytuowany został na probostwo w Kolbuszowej. Wieloletni dziekan mielecki. W roku 1861 wybrany posłem Sejmu Krajowego we Lwowie, następnie poseł wiedeńskiej Rady Państwa w latach 1861-1867 i 1873-1896. Zmarł 30 XI 1896 r. w Kolbuszowej; pochowany został na miejscowym cmentarzu parafialnym ${ }^{1}$.

Dekadę ze swego długiego życia poświęcił na ratowanie mieszkańców Galicji, którzy za udział w powstaniu styczniowym zesłani zostali na Sybir. „Piękna to była karta w życiu X. Ruczki, która mu ogólną wdzięczność zapewniła"2 i przyniosła pamięć żyjących oraz potomnych. W ciągu dziesięciu lat (1863-1873) staraniem o uwolnienie objętych zostało tysiąc osób, spośród których wolność odzy-

* Krzysztof Haptaś - mgr historii oraz bibliotekoznawstwa i informacji naukowo-technicznej, pracownik merytoryczny Muzeum Regionalnego w Mielcu.

${ }^{1}$ B. Kumor, Ruczka Ludwik, w: Polski Stownik Biograficzny (dalej: PSB), t. 32, Wrocław Warszawa - Kraków 1991, s. 595, 596, 597; K. Haptaś, Życiorys proboszcza kolbuszowskiego ks. Ludwika Ruczki, opublikowany po jego śmierci na łamach krakowskiego dziennika „Czas” (2 XII 1896 r.), „Rocznik Kolbuszowski”, 11 (2011), w druku.

${ }^{2}$ K. Haptaś, Życiorys proboszcza kolbuszowskiego ks. Ludwika Ruczki. 
skała około połowa z nich. Dzięki działalności ks. Ruczki mogli powrócić do Galicji ${ }^{3}$.

Na sam koniec należy stwierdzić, że postać ks. Ludwika Ruczki, mimo postępujących badań, jak to stwierdziła M. Micińska, „(...) dzisiaj nie funkcjonuje niemal w pamięci zbiorowej Polaków (a nawet w polu widzenia historyków), a z pewnością zaś zasługuje na zajęcie jak najzaszczytniejszego miejsca w narodowym panteonie" "4. Biogram księdza nadal wymaga wielu uzupełnień, a efektami ostatnich odkryć archiwalnych czy baczniejszego zwrócenia uwagi na teksty już opublikowane są chociażby: propozycja objęcia w 1867 r. probostwa w niedalekim Mielcu (nie doszła do skutku) złożona ks. Ruczce przez kolatorów tamtejszego kościoła parafialnego - Paulinę i Ignacego Suchorzewskich ${ }^{5}$, znalezienie się jego osoby na liście kandydatów do objęcia urzędu metropolity lwowskiego, sporządzonej w roku 1884 przez biskupa tarnowskiego Józefa Alojzego Pukalskiego, czy fakt, iż poprzez matkę spowinowacony był z Maurycym Mochnackim ${ }^{7}$, krytykiem literackim i muzycznym, działaczem politycznym, historykiem powstania listopadowego, publicystą ${ }^{8}$ Nie do końca rozpoznana jest również działalność polityczna ks. Ruczki w okresie posłowania w Wiedniu oraz jego ,życie codzienne" w czasie pobytów w stolicy cesarstwa9. W tym aspekcie interesujące byłoby stwierdzenie, jak mocno absorbowały go obowiązki poselskie, a tym samym jak często wyjeżdżał na posiedzenia, opuszczając Kolbuszowę ${ }^{10}$. Ponadto, badań wymagają m.in.: działalność duszpasterska księdza, zasługi poczynione dla miasta i parafii oraz zajęcia, którym poświęcał się ks. Ruczka w czasie prywatnym, m.in.

${ }^{3}$ M. Micińska, Galicjanie - zesłańcy po powstaniu styczniowym. Zestanie w głąb Cesarstwa Rosyjskiego - Działalność księdza Ludwika Ruczki - Powroty, Warszawa 2004, s. XLVIII.

${ }^{4}$ Tamże, s. XLIII.

${ }^{5}$ K. Haptaś, Propozycja objęcia probostwa mieleckiego dla ks. Ludwika Ruczki (w 1867 roku). Przyczynek do biografii duchownego, w: Parafia kolegiacka Wszystkich Świętych w Kolbuszowej w latach 1510-2010. Studia, szkice i materiaty, red. S. Zych, Kolbuszowa 2010, s. 302-305.

${ }^{6}$ B. Kumor, Obsada metropolii lwowskiej obrzadku łacińskiego w latach 1850-1918, „Folia Societatis Scientiarum Lublinensis”, 22 (1980), Hum. 2, s. 27. Za zwrócenie uwagi na ten fakt dziękuję bardzo serdecznie ks. dr. Sławomirowi Zychowi.

${ }^{7}$ K. Haptaś, Życiorys proboszcza kolbuszowskiego ks. Ludwika Ruczki.

${ }^{8}$ S. Kieniewicz, Mochnacki Maurycy, w: PSB, t. 21, Wrocław - Warszawa - Kraków - Gdańsk 1976, s. 502; A. Bednarek, Mochnacki Maurycy, w: Encyklopedia Katolicka, t. 12, Lublin 2008, kol. 1469.

${ }^{9}$ Garśćszczegółów onimpodajenekrologksiędza Ruczki, cytowany przezH.Dudzińską, wktórym m.in. o tym, że prawie do końca życia odprawiał on wszystkie msze św. za dusze zmarłych członków Koła Polskiego, zamawiane przez posłów w nim zrzeszonych. H. Dudzińska, Ksiądz Ludwik Ruczka, proboszcz kolbuszowski-,,Ojciec Sybiraków”, ,Rocznik Kolbuszowski”, 2 (1987) s. 43. Ponadto odprawiał on w ich imieniu inne nabożeństwa żałobne, przykładowo dnia 26 III $1887 \mathrm{r}$. w Votivkirche w Wiedniuzaśp. Józefa Ignacego Kraszewskiego, wybitnego polskiego pisarza. „Czas”1887, R. 40,nr71 (z 29 III), s. 2.

${ }^{10}$ Prawdopodobnie właśnie obowiązki poselskie były przyczyną jego nieobecności, mimo pełnienia funkcji dziekana, a tym samym nieprzeprowadzenia wizytacji dziekańskiej dekanatu mieleckiego w 1878 r. K. Haptaś, Wizytacja dziekańska parafii kolbuszowskiej z 12 lutego 1878 r., „Rocznik Kolbuszowski”, 10 (2010) s. 75, 77. 
na kolbuszowskiej plebanii. Uskutecznienie tych badań, zważywszy na zbliżające się obchody 150 . rocznicy wybuchu powstania styczniowego, wydaje się być niezbędne, a wręcz naglące, by mogła zostać przedstawiona w pełni historia tego zrywu niepodległościowego, ludzi biorących w nim udział, a szczególnie tych, którzy pomagali powstańcom wziętym do niewoli w wyrwaniu się z niej i powrocie do domu.

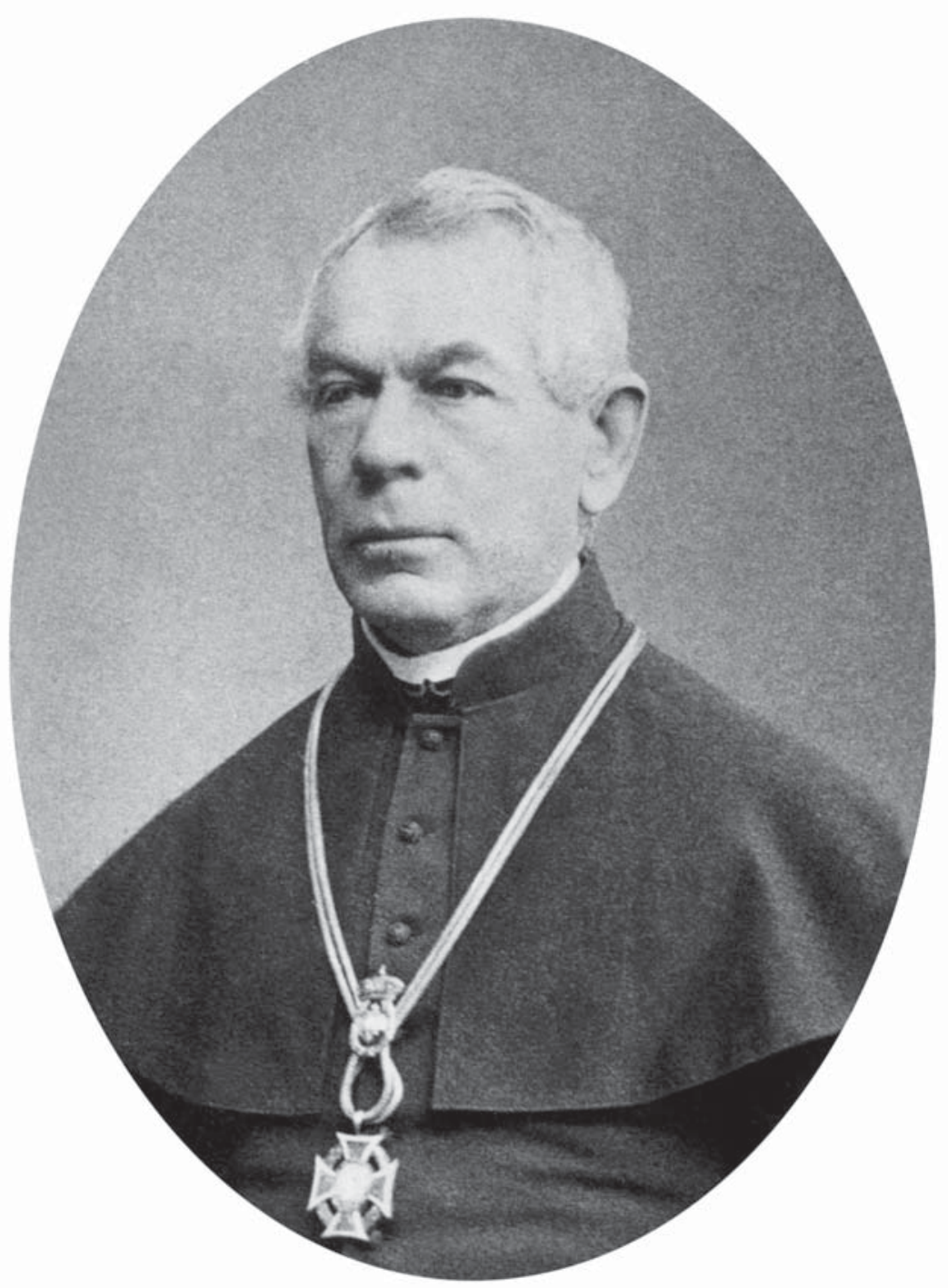

ks. Ludwik Ruczka (1814-1896) - fot. ze zbiorów Muzeum Kultury Ludowej w Kolbuszowej 